\title{
Changes in Ubiquitin and Ubiquitin- Protein Conjugates in the CA1 Neurons After Transient Sublethal Ischemia
}

\author{
TAKASHI HAYASHI, ${ }^{*}$ KOJI TAKADA, AND MAKOTO MATSUDA \\ Department of Biochemistry, The Jikei University School of Medicine, \\ 3-25-8 Nishi-Shinbashi, Minato-ku Tokyo 105 Japan
}

Received December 10, 1990; Accepted April 26, 1991

\begin{abstract}
Ubiquitin is involved in the degradation of denatured proteins in the recovery process after various stresses. To clarify the different responses of the ubiquitin system in the hippocampal neurons after ischemia, we chose $7.5 \mathrm{~min}$ of sublethal forebrain ischemia in the rat. After $7.5 \mathrm{~min}$ of ischemia, ubiquitin-like immunoreactivity (UIR) in most of the hippocampal pyramidal cells, except for the interneurons, diminished after $3 \mathrm{~h}$ of reperfusion, but enhanced UIR and subsequent recovery of UIR were observed in the different hippocampal regions after $24 \mathrm{~h}$ of reperfusion. The most prolonged recovery of UIR in the hippocampal cells was observed in the CA1 neurons after $72 \mathrm{~h}$ of reperfusion. Immunoblot analysis of the proteins extracted from CAl region showed that high-mol-wt ubiquitin conjugates (HMWUC) above $40 \mathrm{kDa}$ increased, whereas free ubiquitin and ubiquitinated histone $2 \mathrm{~A}$ decreased slightly after $4 \mathrm{~h}$ and $24 \mathrm{~h}$ of reperfusion. At 72 h of reperfusion, HMWUC decreased to the original level and free ubiquitin slightly increased beyond the control level. These results suggested that (1) diminished UIR does not always mean depletion of entire ubiquitin-protein conjugates; (2) even after sublethal ischemia, damaged proteins in the CA1 neurons may increase, and it may take a long time for elimination of these proteins.
\end{abstract}

Index Entries: Ischemia; ubiquitin; hippocampus; rat; immunocytochemistry; immunoblotting.

*Author to whom all correspondence and reprint orders should be addressed. 


\section{INTRODUCTION}

The CA1 pyramidal cells of the hippocampus are vulnerable neurons against ischemia/hypoxia and degenerate gradually within several days after transient cerebral ischemia (Kirino, 1982; Pulsinelli et al., 1982). The recovery of the CA1 neurons from ischemic damage takes longer compared with the other neurons because of their susceptibility to ischemia. Although both recovery and cell death must progress simultaneously, many studies about the selective vulnerability to ischemia were usually carried out after lethal ischemia. Because metabolic changes of the affected neurons following sublethal ischemia are reversible, it is possible to observe the complete recovery process from ischemic damage. Although there is some difference between sublethal and critical ischemia, the study of sublethal ischemia may explain why the recovery of specific neurons is delayed.

Ubiquitin is known to be involved in ATP-dependent proteolysis (Finley and Varshavsky, 1985). In some diseases ubiquitin-conjugated abnormal proteins are accumulated in the cell (Manetto et al., 1988; Leigh et al., 1989). Recently, prolonged loss of ubiquitin-like immunoreactivity (UIR) and subsequent neuronal death after ischemia in the CA1 neurons have been reported, and it has been suggested that nonrecovery of UIR might reflect neuronal cell death (Magnusson and Wieloch, 1989). However, changes in ubiquitin and ubiquitin-protein conjugates after ischemia are unknown.

To clarify the changes in the ubiquitin system in the different hippocampal cells after ischemia, we investigated the sequential recovery of UIR in the hippocampus after a brief sublethal ischemia and analyzed the ubiquitin-protein conjugates in the CA1 region by applying immunoblot analysis.

\section{MATERIALS AND METHODS}

\section{Animals}

Male Wistar rats (Jcl: $9 \mathrm{wks}, 250-280 \mathrm{~g}$ ) were subjected to $7.5 \mathrm{~min}$ of forebrain ischemia using the four-vessel occlusion method (Pulsinelli and Brierley, 1979). This ischemic period, after which almost all neurons survived, was determined by preliminary experiment.

\section{Immunocytochemistry}

The rats subjected to operation for each time-point (control: $3,3 \mathrm{~h}: 4$, $24 \mathrm{~h}: 4,48 \mathrm{~h}: 4,72 \mathrm{~h}: 4,5 \mathrm{~d}$ of reperfusion: 4 ) were deeply anesthetized with pentobarbital $(40 \mathrm{mg} / \mathrm{kg}$, ip) and perfused transcardially with icecold $4 \%$ paraformaldehyde in a $0.1 \mathrm{M}$ phosphate buffer $(\mathrm{pH} 7.4)$ following brief perfusion with saline. The brain was removed and postfixed in 
the same fixative for $4 \mathrm{~h}$ at $4^{\circ} \mathrm{C}$. Specimens were rinsed in the same buffer and sectioned with a Microslicer (Dosaka EM, Japan) at $35 \mu M$. Freefloating sections were processed for immunostaining as described elsewhere. Briefly, after blocking in 10\% normal swine serum for $1 \mathrm{~h}$, sections were incubated for $72 \mathrm{~h}$ in $0.5 \mu \mathrm{g} / \mathrm{mL}$ of an affinity-purified rabbit antiubiquitin antibody at $4^{\circ} \mathrm{C}$. Next, sections were washed and incubated for $2 \mathrm{~h}$ in biotinylated swine antirabbit IgG (DAKOPATTS, Denmark, 1:500). After washing, sections were incubated with avidin and biotinylated peroxidase complex (DAKOPATTS, Denmark, 1:200) for $2 \mathrm{~h}$ and then developed using 3,3'-diaminobenzidine. Normal rabbit serum, or the second antibody alone, was used for controls.

\section{Immunoblotting}

Animals (control: 7 , immediately after reperfusion $3,4 \mathrm{~h}: 4,24 \mathrm{~h}: 4$, $72 \mathrm{~h}: 4,96 \mathrm{~h}: 3,5 \mathrm{~d}$ of reperfusion: 3 ) were decapitated, and the CA1 region was quickly dissected on ice. Specimens were sonicated briefly in an extraction solution containing $2 \%$ SDS, 5\% 2-mercaptoethanol, $6 \mathrm{M}$ urea, $2 \mathrm{mM} N$-ethylmaleimide, $1 \mathrm{mM}$ phenylmethylsulfonyl fluoride, 10 $\mu \mathrm{g} / \mathrm{mL}$ pepstatin A, $10 \mu \mathrm{g} / \mathrm{mL}$ leupeptin, $10 \mu \mathrm{g} / \mathrm{mL}$ antipain, $10 \mu \mathrm{g} / \mathrm{mL}$ chymostatin, and $5 \mathrm{mM}$ EGTA in $50 \mathrm{mM}$ Tris- $\mathrm{HCl}$ (pH 6.8). Samples (35 $\mu$ g protein per lane) were electrophoresed using a 10-18\% linear gradient separating gel (Laemmli, 1970) and then electrotransferred to a polyvinylidene difluoride membrane (pore size $0.22 \mu M$ ). The membranes were autoclaved at $120^{\circ} \mathrm{C}$ for $30 \mathrm{~min}$ (Swerdlow et al., 1986) and probed with the same antiubiquitin antibody as used earlier (185 $\mathrm{ng} / \mathrm{mL})$, followed by alkaline-phosphatase-conjugated antirabbit IgG (Sigma, St. Louis, MO, USA, 1:1000). Bound antibodies were located by exposure to nitroblue tetrazolium and 5-bromo-4 chloro-3-indolyl phosphate. Normal rabbit serum (1:300) was used as a control in the place of the primary antibody.

Protein concentration was determined by the method of Lowry et al. (1951) as modified by Bensadoun and Weinstein (1976) using bovine serum albumin for standard protein.

\section{Specificity of the Antibody}

The preparation and the specificity of the antibody against ubiquitin and ubiquitin conjugates have been described (Ishibashi et al., 1991).

\section{RESULTS}

\section{Immunocytochemistry}

In the control animals, UIR was faintly observed throughout the hippocampal neurons (Fig. 1A, B). UIR was noted in the nucleus, cell soma and dendrite. After $3 \mathrm{~h}$ of reperfusion following $7.5 \mathrm{~min}$ of isch- 

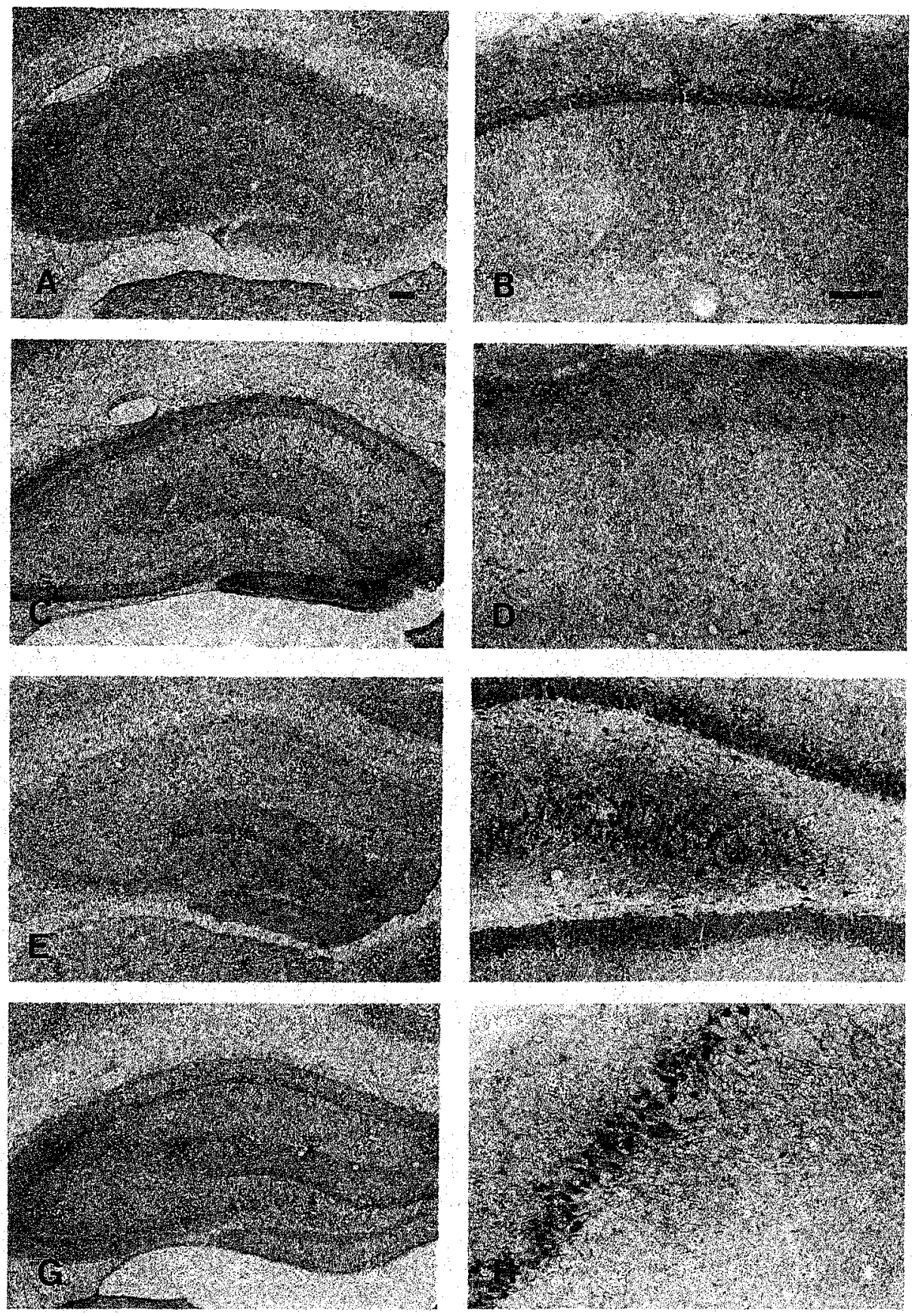

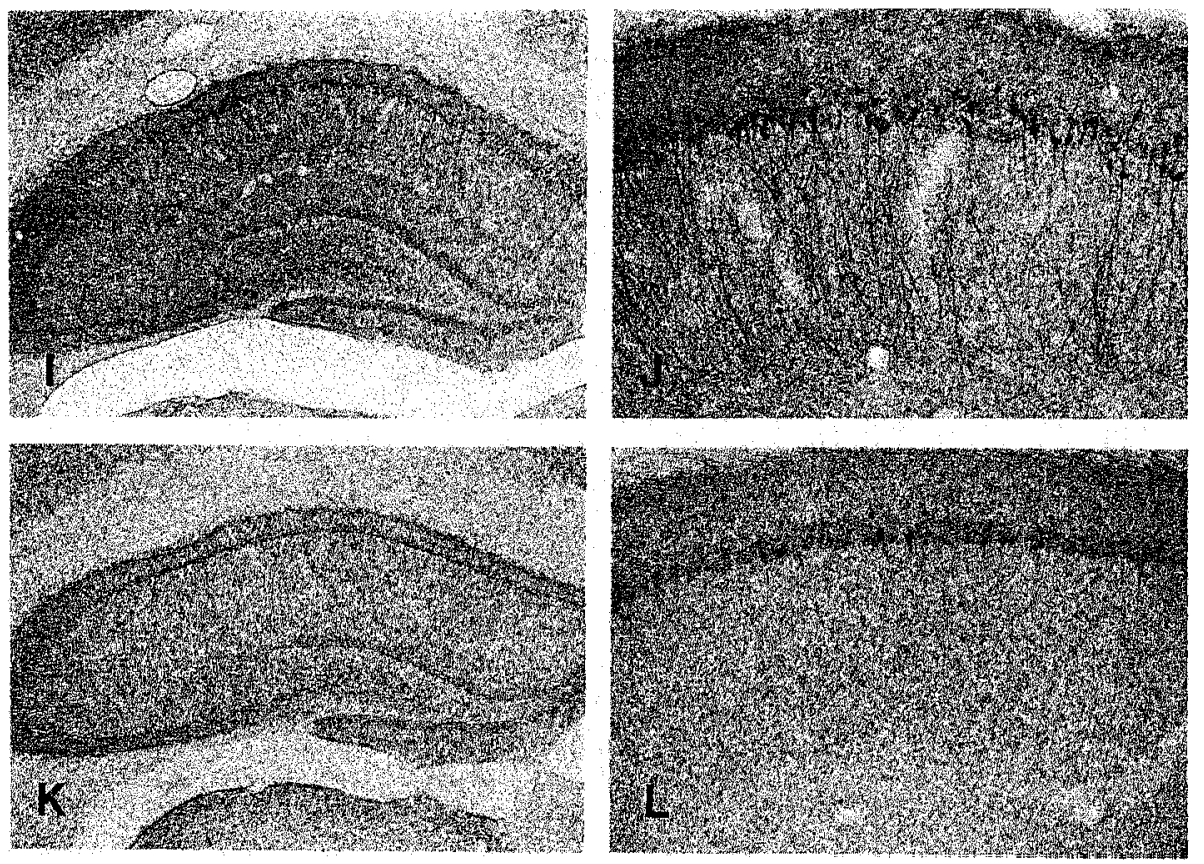

Fig. 1. Immunostaining of the rat hippocampi with the polyclonal antiubiquitin antibody; Control rat (A, B), $3 \mathrm{~h}(\mathrm{C}, \mathrm{D}), 24 \mathrm{~h}(\mathrm{E}, \mathrm{F}), 48 \mathrm{~h}(\mathrm{G}, \mathrm{H}), 72 \mathrm{~h}$ (I, $\mathrm{J})$, and $5 \mathrm{~d}(\mathrm{~K}, \mathrm{~L})$ of reperfusion after $7.5 \mathrm{~min}$ of ischemia. Magnification of CA1 $(B, D, J$, and L), CA2 (H), and CA4 (F) region. (Scale bar $=200 \mu \mathrm{m}$ in A, $100 \mu \mathrm{m}$ in $B)$

emia, UIR was reduced in both the cell nucleus and the cytoplasm in almost all hippocampal neurons except for the interneurons (Fig. 1C, D). At $24 \mathrm{~h}$, the dentate granule cells and the CA3 neurons recovered their UIR, and intense UIR was observed in the CA4 neurons (Fig. 1E, F). Enhanced immunoreactivity was noted in the nucleus, cell soma, and dendrite. The same change was observed at $48 \mathrm{~h}$ in the CA2 and lastly at $72 \mathrm{~h}$ in the CA1 neurons (Fig. 1G-J). These strong immunoreactive neurons were hardly observed, and no obvious cell loss was found in the CA1 region at $5 \mathrm{~d}$ after reperfusion (Fig. $1 \mathrm{~K}, \mathrm{~L}$ ).

\section{Immunoblotting}

As shown in Fig. 2, many ubiquitinated proteins were recognized in the control animals (lane 1). Immediately after ischemia, ubiquitinated proteins decreased with no remarkable changes in free ubiquitin (lane 2). At $4 \mathrm{~h}$ and $24 \mathrm{~h}$ of reperfusion after $7.5 \mathrm{~min}$ of ischemia, high-mol-wt ubiquitin conjugates (HMWUC) above $40 \mathrm{kDa}$ (approx) increased whereas ubiquitinated histone $2 \mathrm{~A}$ and free ubiquitin slightly decreased (lane 3 , 4). At $72 \mathrm{~h}$, HMWUC decreased, and ubiquitinated histone $2 \mathrm{~A}$ and free ubiquitin increased to the control level (lane 5). The free ubiquitin in- 


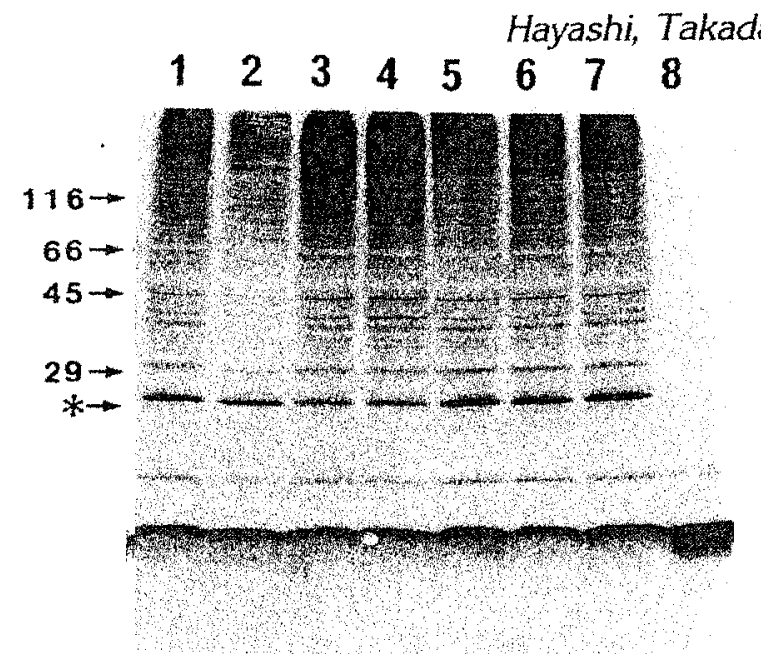

Fig. 2. Immunoblotting of the polyclonal antiubiquitin antibody in samples of CAI region; Control (1), immediately after reperfusion

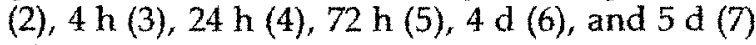
of reperfusion after $7.5 \mathrm{~min}$ of ischemia, $90 \mathrm{ng}$ ubiquitin (8). Molecular-weight markers are indicated on the left in kilodaltons. Asterisk ( $\left.{ }^{*}\right)$ could correspond to ubiquitinated histone $2 \mathrm{~A}$.

creased slightly beyond the control level at $72 \mathrm{~h}$ of reperfusion. No obvious changes were noted after 4 and $5 \mathrm{~d}$ of reperfusion compared with the control (lane 6,7 ). Specific ubiquitinated proteins induced by the ischemia could not be observed.

\section{DISCUSSION}

In this article, we described the different responses of the ubiquitin system in the hippocampal neurons after sublethal ischemia. Temporal profiles of the neuronal cell deaths in the hippocampal neurons after lethal ischemia have been shown in the following order: CA4-CA2-CA1 neurons (Pulsinelli et al., 1982). This order would correspond to the appearance of the enhanced UIR after sublethal ischemia. Because these changes seemed to coincide with the appearance of heat-shock proteinlike immunoreactivity after lethal ischemia (Vass et al., 1988), and ubiquitin is known to be involved in heat-shock response, the enhanced UIR may imply a heat-shock related change after ischemia.

Immediately after reperfusion, the decrease of HMWUC in the immunoblotting may have resulted from the decreased ATP. ATP may recover at $4 \mathrm{~h}$ and $24 \mathrm{~h}$ of reperfusion (Pulsinelli and Duffy, 1983), the increase of HMWUC and the decrease of free ubiquitin might reflect the recovery of ubiquitination with the consumption of free ubiquitin. We found there was a good correlation between changes in UIR in the 
cytoplasm and free ubiquitin but not HMWUC. In addition, if HMWUC is involved in UIR, UIR should diminish according to the decrease of HMWUC immediately after ischemia. But Magnusson and Wieloch (1989) have reported that no remarkable changes in UIR were noted in the CA1 neurons in this period. These differences between the changes in UIR and in HMWUC might be explained by the antibody hardly binding HMWUC because of its hidden epitope in the CA1 neurons. Furthermore, we obtained similar results in the immunoblotting with the different monoclonal antibodies to ubiquitin (unpublished data). We cannot, however, ignore the contribution of the ubiquitinated histone $2 \mathrm{~A}$ to the UIR in the nucleus and the involvement of the interneurons, which never lose UIR but rather show enhanced UIR after recirculation, in the increase of HMWUC. However, it must be emphasized again that diminished UIR does not always mean depletion of the entire ubiquitin conjugates.

In this study, we have described how the terminations of the ubiquitin responses are delayed in the CA1 neurons compared with the other regions after sublethal ischemia. It is unknown whether the strength of the early ischemic damage or the sustained stress after reperfusion may contribute to such delay. Reduced UIR in CA1 neurons $48 \mathrm{~h}$ after sublethal ischemia does not always mean neuronal cell death but these neurons are in an unstable condition in this period. It is an interesting problem how the repetitive sublethal ischemia has influenced the CA1 neurons in this period. Kitagawa et al. (1990) have reported that the CA1 neurons exposed to sublethal ischemia develop a tolerance against the following lethal ischemia in this period. Accumulated abnormal proteins, such as paired helical filaments, are frequently observed in CA1 neurons in normal aging, and Alzheimer's disease might result from a response of the CA1 neurons against the brief but repetitive ischemia.

\section{REFERENCES}

Bensadoun A. and Weinstein D. (1976) Assay of proteins in the presence of interfering materials. Anal. Biochem. 70, 241-250.

Finley D. and Varshavsky A. (1985) The ubiquitin system: Functions and mechanisms. Trend. Biochem. Sci. 10, 343-347.

Ishibashi Y., Takada K., Joh K., Ohkawa K., Aoki T., and Matsuda M. (1991) Ubiquitin immunoreactivity in human malignant tumours. Br. J. Cancer 63, $320-322$.

Kirino T. (1982) Delayed neuronal death in the gerbil hippocampus following ischemia. Brain Res. 239, 57-69.

Kitagawa K., Matsumoto M., Tagaya M., Hata R., Ueda H., Niinobe M., Handa N., Fukunaga R., Kimura K., Mikoshiba K., and Kamada, T. (1990) "Ischemic tolerance" phenomenon found in the brain. Brain Res. 528, 21-24.

Laemmli U. K. (1970) Cleavage of structural proteins during the assembly of the head of bacteriophage T4. Nature 227, 680-685. 
Leigh P. N., Probst A., Dale G. E., Power D. P., Brion J. -P., Dodson A., and Anderton B. H. (1989) New aspects of the pathology of neurodegenerative disorders as revealed by ubiquitin antibodies. Acta Neuropathol. (Berlin) 79, $61-72$.

Lowry O. H., Rosebrough N. J., Farr A. L., and Randall R. J. (1951) Protein measurement with the Folin phenol reagent. J. Biol. Chem. 193, 265-275.

Magnusson K. and Wieloch T. (1989) Impairment of protein ubiquitination may cause delayed neuronal death. Neurosci. Lett. 96, 264-270.

Manetto V., Perry G., Tabaton M., Mulvihill P., Fried V. A., Smith H. T., Gambetti $P$., and Autilio-Gambetti L. (1988) Ubiquitin is associated with abnormal cytoplasmic filaments characteristic of neurodegenerative diseases. Proc. Natl. Acad. Sci. USA 85, 4501-4505.

Pulsinelli W. A. and Brierley J. B. (1979) A new model of bilateral hemispheric ischemia in the unanesthetized rat. Stroke 10, 267-272.

Pulsinelli W. A., Brierley J. B., and Plum F. (1982) Temporal profile of neuronal damage in a model of transient forebrain ischemia. Ann. Neurol. 11, 491-498.

Pulsinelli W. A. and Duffy T. E. (1983) Regional energy balance in rat brain after transient forebrain ischemia. J. Neurochem. 40, 1500-1503.

Swerdlow P. S., Finley D., and Varshavsky A. (1986) Enhancement of immunoblot sensitivity by heating of hydrated filters. Anal. Biochem. 156, 147-153.

Vass K., Welch W. J., and Nowak T. S., Jr. (1988) Localization of 70-kDa stress protein induction in gerbil brain after ischemia. Acta Neuropathol. (Berlin) 77, $128-135$. 